\title{
Sistema brasileiro de financiamento à exportação
}

Wagner de Medeiros, gerente de Financiamento à Exportação da Carteira de Comércio Exterior do Banco do Brasil SIA -

Cacex.

O sistema brasileiro de financiamento à exportação, hoje, procura abranger todas as fases do processo de exportação, desde a prospecção do mercado até a produção do bem e a comercialização externa, seja para bens de capital ou de consumo durável, seja para serviços através da venda de projetos integrados.

Contudo, muito embora desde a sua criação em 1953, a Cacex, que é um departamento do Banco do Brasil, tenha atendido, entre suas funções, ao financiamento de exportação, apenas há poucos anos, efetivamente, passamos a atuar no financiamento das exportações - e falo das exportações, não das importações.

Basicamente, a nossa função, a função do Banco do Brasil, a função do sistema brasileiro é de financiar a exportação brasileira. A esse interstício caberia ser acrescentado mais doze anos de incubação da idéia de contar-se com organismo que servisse efetivamente ao propósito de financiar a exportação brasileira. Com efeito, em 1941, foi criada no Banco do Brasil a antecessora da Cacex, a Carteira de Comércio de Exportação e Importação - Cecim, que já tinha o propósito de financiar as exportações. Já se sentia na ocasião a conveniência de o Brasil contar com organismo que sustentasse e impulsionasse esse intercâmbio comercial com o estrangeiro, a exemplo do que ocorria em outros países, no caso do Eximbank nos Estados Unidos, na Inglaterra, na França e em outros países.

O pioneirismo da idéia de criação no Brasil de organismo para o comércio exterior, tal como ocorreu em 1941, pode bem ser medido se lembrarmos que, àquela época esse comércio brasileiro girava em torno de 550 milhões de dólares, dos quais $279 \mathrm{mi}$ Ihões se referiam às exportações, lideradas pelo café, com $40 \%$.

Infelizmente, as medidas de defesa econômica que se tornaram necessárias em conseqüência da erupção da Segunda Guerra Mundial levaram a alterações, passando então esta carteira, chamada Cecim, a ser conhecida como órgão de fiscalização e controle do movimento mercantil com o exterior,
Wagner de Medeiros

função à qual, também, registre-se, com a criação da Cacex, também se engajou.

Não escaparia à própria Cacex as suas funções, até que fosse regulamentada a sua existência pela Lei . $^{\circ}$ 5.025, de 1976, que modificou o enfoque governamental restrito, até então dominante em matéria de exportação.

Com a Lei n. 5.025 estabeleceu-se sistemática para o financiamento das atividades exportadoras, criando-se um fundo, no Banco Central, chamado Fundo de Financiamento à Exportação - Finex. Enquanto continuou a cargo dos departamentos de câmbio dos bancos o financiamento de bens que, pelas peculiaridades de seu comércio com o estrangeiro, demandava prazo maior para pagamento, ao que os bancos comerciais nem sempre poderiam atender. Essa nova modalidade de financiamento ficou a cargo da Cacex e se destinava, precipuamente, a atender às exportações de bens de capital e de bens de consumo durável, cujas exportações se faziam até então apenas por prazos de 180 dias, e, depois, com a criação desse mecanismo de financiamento, foi possível a concessão de financiamentos acima de 180 dias, a prazos médios e longos.

Portanto, voltaram a realizar-se as atividades da Cacex, com a dinâmica do comércio internacional no campo financeiro preenchendo lacuna que, dentro da orientação governamental em que se enfatizam vendas de manufaturados, constituiam obstáculos à atividade exportadora nacional e de consumo durável a contar com esse instrumento financeiro sui generis para apoio de sua ação vendedora.

A característica da Cacexé constituir um centro que mexa com a atividade de banqueiros e, em certos casos, com atividades promocionais. $\mathrm{A} \mathrm{Ca}$ cex, pela flexibilidade operacional e em face do apoio que recebe da infra-estrutura do Banco do Brasil, inserida como está nesse estabelecimento, no país e no exterior, difere dos organismos bancários que atuam nas demais nações, com objetivo de financiar a exportação daqueles mesmos bens, obviamente daqueles de cunho mais comercial; não me refiro aos 
bancos de desenvolvimento que já têm por definição esta função.

O sistema de financiamento de exportação pela Cacex teve, então uma natural evolução no tempo, acompanhando o crescimento, o volume e a complexidade do comércio. Limitando as suas atividades inicialmente a financiamentos de modestas vendas de máquinas ao exterior e à compra e venda de excedentes exportáveis de alguns produtos primários, o campo de sua atuação ampliou-se acentuadamente, abrangendo, hoje, todas as fases do processo de exportação, como já citei anteriormente. Para isso, tivemos que fazer modificações na estrutura organizacional e na própria estrutura de financiamento à exportação. E, naturalmente, com o crescimento desse comércio e com a necessidade e o enfoque dado ao apoio de grandes projetos e à exportação de serviços, porque até então estávamos muito voltados para as fontes de financiamento em cruzeiros apenas - porque esse fundo chamado Finexé um fundo em cruzeiros - passamos a ter que nos abrir mais, a nos voltar mais para o mercado internacional e para buscar cooperações, para que pudéssemos financiar projetos de grande magnitude. Então, criou-se, a partir de 1979 (e isso já seria um passo para a volta ao mercado internacional, em termos de apoio de financiamento à exportação - através de um instrumento do Banco Central, cujo número é a Resolução 509 e cujo nome é Equalização de Taxas), um sistema que permitiu, a todos os bancos brasileiros autorizados a operar em câmbio e, logo depois da Resolução 509, através da Resolução 637, aos bancos estrangeiros, colocarem recursos à disposição dos exportadores brasileiros para financiar a exportação. Claro que a prazos e condições compatíveis com os do mercado internacional e com aquelas condições que a Cacex oferecia até 1979 e que continua oferecendo, porque os sistemas coexistem.

Nesse caso, o que o Banco do Brasil faz, através da Cacex e mediante o instrumento criado pelo Banco Central, é assegurar ao banqueiro que coloca recursos à disposição do financiamento à exportação, quer de exportação de serviços e bens de consumo ligados ao projeto, quer de venda isolada de bens, assegurar a esse banqueiro a diferença de taxa de juros entre aquela praticada no mercado internacional e aquela que será paga pelo importador do bem ou do projeto. Portanto, equalizamos a taxa de juros, pagando, além disso, uma comissão ao banqueiro interveniente.

Esse sistema mostrou-se extremamente eficiente; já financiou até hoje cerca de dois e meio biIhões de dólares. Ele começou em 1979, mas nesse ano praticamente não operou, iniciando-se de fato em 1980; em 1981, foi bastante efetivo e já em 1982 superou as expectativas. As suas aplicações ultrapassam as próprias aplicações da Cacex, no que diz respeito a financiamento à exportação.

Vê-se, pois, que estamos voltados para buscar cooperação, para co-financiar projetos no exterior. Há uma primeira experiência do projeto de Moçambique; há uma segunda experiência que estamos começando a viver em Cabo Verde, com financiamento em que a Cacex vai co-participar, através de alguns fundos; e desde já, com banqueiros estrangeiros ou banqueiros nacionais, estamos co-financiando e participando em financiamentos de projetos de longo prazo e de grande valor, não só de exportações de bens brasileiros, de serviços e equipamentos, mas, também, de custos locais. Inclusive com relação ao Egito, com financiamento brasileiro, com exportações de navios e outros tipos de exportação de bens de capital também.

Essas informações parecem importantes porque, na medida em que se vai tornando complexo o relacionamento financeiro, vamos sentindo que se vai tornando complexo o relacionamento financeiro, vamos sentindo a necessidade de fato de ter meIhores condições de adaptar contratos, e a própria Cacex, em termos de contratos de financiamento de exportação. Já mandamos funcionários para o exterior fazer cursos, a fim de começar a adaptar os nossos contratos à realidade do comércio internacional, porque nós próprios, visitando alguns países, negociando linhas de crédito com alguns países, $\mathrm{Co}$ meçamos a sentir que aquilo que se praticava até então está um pouco fora da realidade internacional e, em certos casos, embaraça as negociações. 